\title{
Blended Phenotype of Silver-Russell Syndrome and SPG50 Caused by Maternal Isodisomy of Chromosome 7
}

Marvin Ziegler, Bianca E. Russell, MD, Kathrin Eberhardt, Gregory Geisel, BS, Angelica D'Amore, PhD, Mustafa Sahin, MD, PhD, Harley I. Kornblum, MD, PhD, and Darius Ebrahimi-Fakhari, MD, PhD

Neurol Genet 2021;7:e544. doi:10.1212/NXG.0000000000000544

\section{Abstract}

\section{Objective}

Uniparental isodisomy can lead to blended phenotypes of imprinting disorders and autosomal recessive diseases. To determine whether a complex neurodevelopmental disorder was caused by uniparental isodisomy, a detailed clinical and molecular characterization was performed.

\section{Methods}

A combination of clinical, molecular, and imaging data and functional studies in patient-derived fibroblasts.

\section{Results}

We report a 4-year-old female with a blended, complex phenotype of Silver-Russell syndrome (SRS) and hereditary spastic paraplegia type 50 (SPG50) caused by total maternal isodisomy of chromosome 7 (UPiD(7)mat) and a loss-of-function variant in AP4M1 (NM_00472.3: c.59$1 G>C$, IVS1-1G $>C$ ). Functional studies in patient-derived fibroblasts confirmed the loss of adaptor protein complex 4 function. Distinctive facial features, intrauterine growth restriction, short stature, feeding difficulties, and severe gastroesophageal reflux were consistent with SRS. Features associated with SPG50 included early-onset epilepsy, episodes of stereotypical laughter, and thinning of the corpus callosum and ventriculomegaly on brain MRI. Symptoms shared by both syndromes such as developmental delay, short stature, and axial and appendicular hypotonia were also present. Notably, other common manifestations of SPG50 such as microcephaly or spasticity had not developed yet.

\section{Conclusions}

This case highlights that atypical clinical features in patients with well-described imprinting disorders should lead to investigations for recessive conditions caused by variants in genes that localize to the region of homozygosity.

\author{
Correspondence \\ Dr. Ebrahimi-Fakhari \\ darius.ebrahimi-fakhari@ \\ childrens.harvard.edu
}




\section{Glossary}

AP-4 = adaptor protein complex 4; ATG9A = autophagy-related protein 9A; CDC $=$ Centers for Disease Control and Prevention; SPG50 = spastic paraplegia type 50; SRS = Silver-Russell syndrome; SSMD = strictly standardized mean difference.

Uniparental isodisomy can lead to imprinting disorders and the unmasking of autosomal recessive disorders due to a single parental pathogenic variant. Silver-Russell syndrome (SRS) (OMIM \#180860) is a rare but well-known genetic syndrome that can be caused by an imprinting defect and is characterized by pre- and postnatal growth restriction, feeding difficulties, developmental delay, and distinctive facial features. ${ }^{1}$ Maternal uniparental disomy of chromosome $7(\operatorname{UPiD}(7) m a t)$ is known to cause SRS in a subset of patients. ${ }^{2}$ The AP4M1 gene is located on chromosome 7 , and biallelic loss-of-function variants lead to hereditary spastic paraplegia type 50 (SPG50, OMIM \#612936), 1 of 4 ultra-rare forms of complex hereditary spastic paraplegia caused by deficiency of the adaptor protein complex 4 (AP-4). Here, we describe a 4-year-old female with a blended, complex phenotype of SRS and SPG50 caused by UPiD(7)mat and a novel loss-of-function variant in AP4M1.

\section{Methods}

\section{Standard Protocol Approvals, Registrations, and Patient Consents}

This study was approved by the Institutional Review Board at Boston Children's Hospital (IRB-P00033016). Written consent and permission to publish the images in figure 1 were obtained.

\section{Functional Assays}

Primary skin fibroblasts were derived and cultured according to established protocols. ${ }^{5,6}$ Immunocytochemistry, high-content confocal imaging, and Western blotting were performed as described previously. ${ }^{6}$ Each experiment was performed in 3 biological replicates. Robust $Z^{\prime}$ score and strictly standardized mean difference (SSMD) were calculated to ensure robust assay performance. Statistical analysis was performed with Prism version 8.0 (GraphPad Software, Inc., La Jolla, CA). Data are shown as mean \pm SEM. Groups were compared using the unpaired $t$ test. $p<0.05$ was considered significant.

\section{Data Availability}

Data are available from the corresponding author on reasonable request.

\section{Case Report}

\section{Clinical Findings}

The proband was born at 37-week gestational age via uncomplicated Caesarean section for intrauterine growth restriction to nonconsanguineous parents of mixed European background. There was no significant family history. Prenatal ultrasound was notable for mild ventriculomegaly. Birth weight was 2,155 g $(Z=-2.44$, Centers for Disease Control and Prevention $[\mathrm{CDC}])$, length was $46 \mathrm{~cm}(Z=-1.79$, $\mathrm{CDC})$, and head circumference was $34 \mathrm{~cm}(Z=-0.72, \mathrm{CDC})$. Neonatal course was notable for feeding difficulties and transient hypoglycemia. Significant feeding difficulties and severe gastroesophageal reflux continued throughout early childhood requiring the placement of a gastrostomy tube. At age 2 years, growth hormone therapy started given her short stature. At nearly 4 years of age, her height was $90 \mathrm{~cm}(Z=$ $-2.37, \mathrm{CDC})$, weight was $11.6 \mathrm{~kg}(Z=-2.66, \mathrm{CDC})$, and head circumference was $49.5 \mathrm{~cm}(Z=0.19$, World Health Organization) consistent with relative macrocephaly. Several distinctive facial features were present (figure 1A and table 1).

Global developmental delay and significant hypotonia have been noted since infancy. At age 4 years, the proband can sit without support, crawl, and stand with support and ankle-foot orthoses. She does not walk independently likely because of significant axial and appendicular hypotonia. She is nonverbal but signs, understands basic commands, responds appropriately to emotional stimuli, and recently began to comprehend object permanence. Recurrent episodes of stereotypical laughter were noted and had no electrographic correlate on EEG. There is no history of developmental regression or progressive loss of motor skills. No spasticity or extrapyramidal movement disorders have been noted to date (Modified Ashworth Scale score of 0 ). At age 3 years, the proband developed both focal seizures with impaired awareness and generalized seizures, including several episodes of convulsive status epilepticus. Seizures remain refractory and are currently treated with levetiracetam, topiramate, and cannabidiol. EEG showed multifocal epileptiform discharges. Brain MRI obtained at age 3 years demonstrated thinning of the corpus callosum (particularly of the posterior parts), nonspecific T2 hyperintensity of the white matter, and ventriculomegaly, mainly in the form of colpocephaly, pointing to a loss of periventricular white matter (figure 1B).

\section{Molecular Findings}

A whole-genome array comparative genomic hybridization with single nucleotide polymorphism analysis performed at age 18 months with parental controls identified total maternal uniparental isodisomy for the entire chromosome 7 (UPiD(7)mat). In combination with the clinical presentation that fulfilled the Netchine-Harbison clinical scoring system criteria, $^{7}$ this led to a diagnosis of SRS. Because of refractory epilepsy and other findings outside the typical clinical spectrum of SRS (table 1), exome sequencing was performed and identified a c.59-1G $>$ C (IVS1-1G $>$ C) intronic variant in AP4M1 (NM_00472.3). This maternally inherited variant 

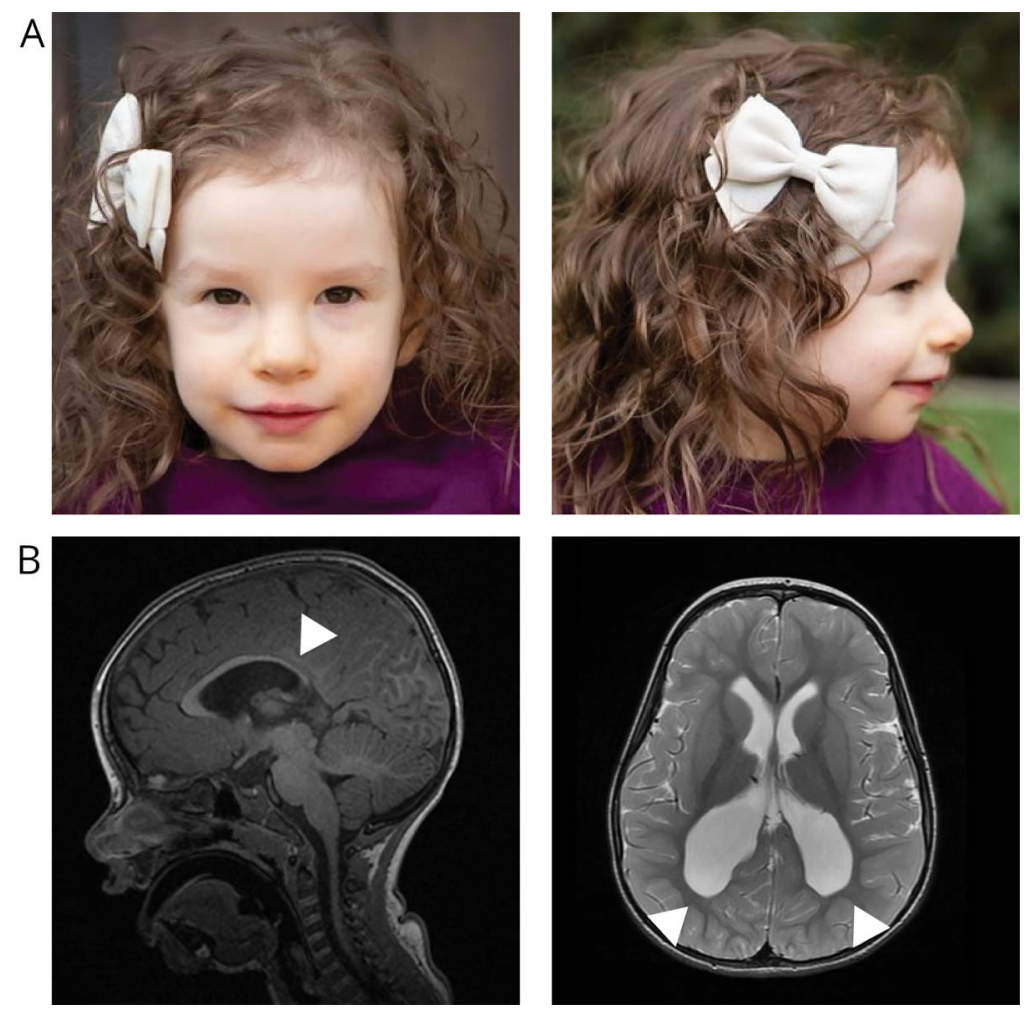

(A) Facial features consist of a high forehead, frontal bossing, flat and prominent nasal bridge, epicanthal folds, micrognathia, and a tented upper lip. (B) Brain MRI at age 3 years: (Left) Sagittal T1-weighted image showing a thin corpus callosum with predominant thinning of the splenium (white arrows). (Right) Axial T2-weighted image showing ventriculomegaly mainly in the form of colpocephaly (white arrows) due to loss of periventricular white matter.

localizes to a region of homozygosity secondary to $\operatorname{UPiD}(7)$ mat and is predicted to result in a null allele due to its effect on a canonical splice site. The variant is novel as it is not present in any of the other 64 individuals with AP4M1-associated SPG50 enrolled in the AP-4-HSP International Registry (unpublished and reference 4) and absent from the Genome Aggregation Database (gnomAD v3, gnomad.broadinstitute. org, accessed August 20, 2020).
To confirm a loss of AP4M1 function, functional studies were performed in cultured patient-derived skin fibroblasts. Fibroblasts of the proband's mother (unaffected heterozygous carrier) served as controls. Western blot analysis of whole-cell lysates showed a reduction in adaptor-related protein complex 4 subunit epsilon 1 protein levels, a surrogate for AP-4 complex formation, ${ }^{6}$ and the characteristic accumulation of the AP-4 cargo protein autophagy-related protein 9A (ATG9A) (figure 2A).

Table 1 Phenotypes Caused by UPiD(7)mat and a Loss-of-Function Variant in AP4M1 (NM_00472.3: c.59-1G>C, IVS1-1G>C)

\begin{tabular}{|c|c|}
\hline Silver-Russell syndrome & AP4M1-associated SPG50 \\
\hline \multicolumn{2}{|c|}{ Developmental delay (typically mild in Silver-Russel syndrome and moderate to severe in SPG50) } \\
\hline \multicolumn{2}{|l|}{ Hypotonia } \\
\hline \multicolumn{2}{|l|}{ Short stature } \\
\hline $\begin{array}{l}\text { Distinctive features: hypotonic facies, frontal bossing, triangular face, micrognathia, } \\
\text { tented upper lip with subtle down turn of corners of the mouth, overlapping toes, } \\
\text { and joint hypermobility }\end{array}$ & $\begin{array}{l}\text { Stands with support and ankle braces, independent walking } \\
\text { not achieved at age } 4 \text { y }\end{array}$ \\
\hline Intrauterine growth restriction and postnatal growth failure & Epilepsy \\
\hline Feeding difficulties and severe gastroesophageal reflux & Episodes of stereotypic laughter \\
\hline Relative macrocephaly & $\begin{array}{l}\text { Thin corpus callosum, ventriculomegaly, colpocephaly, and } \\
\text { periventricular white matter abnormalities }\end{array}$ \\
\hline
\end{tabular}


Further characterization using a high-content confocal imaging assay (screening of $>4 \times 10^{4}$ cells per condition, average robust $\mathrm{Z}^{\prime}=0.56$, average $\mathrm{SSMD}=6.18$ ) demonstrated a mislocalization of ATG9A (figure 2B) with accumulation in the trans-Golgi network area, similar to the pattern seen in fibroblasts of other patients with AP4M1-associated SPG50. ${ }^{6}$ Taken together, these results provide functional evidence for a loss of AP-4 function.

\section{Discussion}

This clinical report highlights that atypical clinical features in patients with imprinting disorders due to isodisomy may be related to the unmasking of autosomal recessive disorders caused by genes localized to the region of homozygosity. Features consistent with SRS in this patient include the characteristic facial appearance, pre- and postnatal growth restriction, and significant feeding difficulties, meeting established clinical criteria. ${ }^{7}$ Most individuals with $\operatorname{UPiD}(7)$ mat-associated SRS have milder developmental delays than reported in our patient who ambulates only with significant support and is nonverbal. ${ }^{8}$ Similarly, seizures are not commonly reported in SRS, ${ }^{1,2,7,8}$ which resulted in additional diagnostic investigations including neuroimaging and exome sequencing. A thinning of the posterior corpus callosum and ventriculomegaly, though not specific, are common features

Figure 2 Functional Characterization Reveals Loss of AP-4 Function

A AP4E1

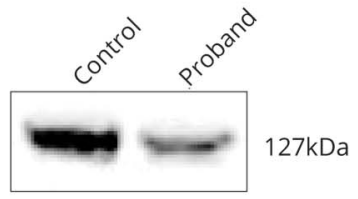

ATG9A

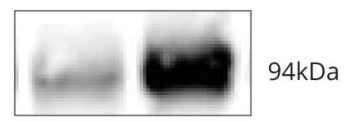

a-Tubulin

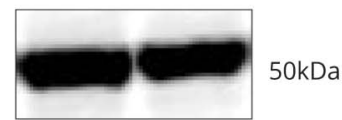

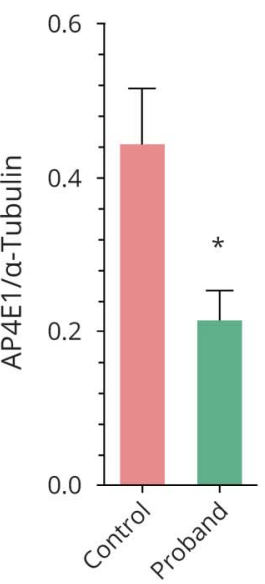

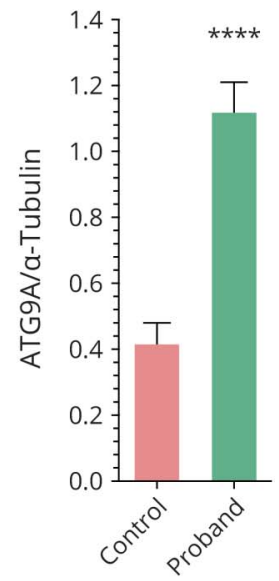

- TGN46 -ATG9A

B
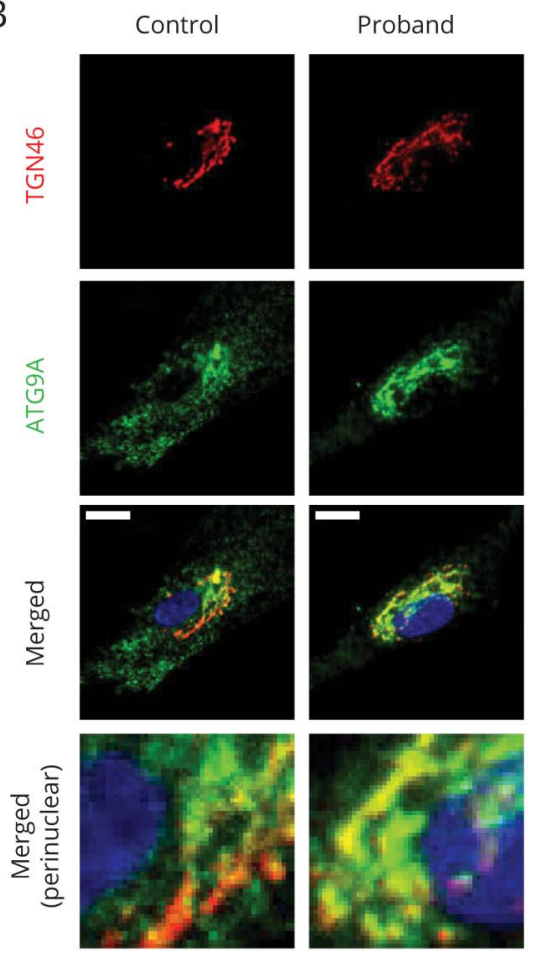

Control
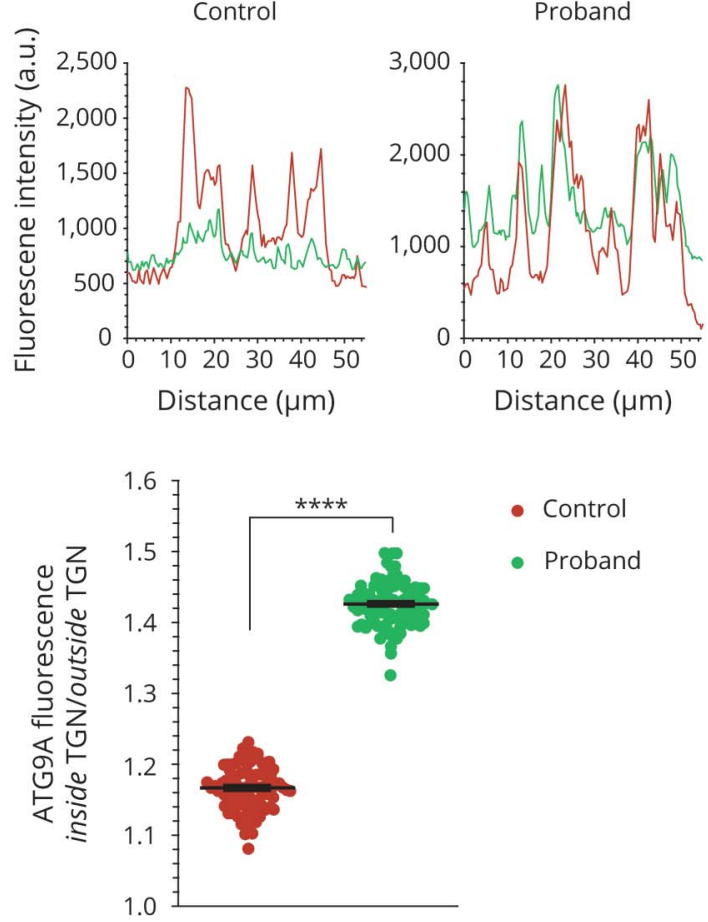

(A) Western blot of whole cell lysates from fibroblasts derived from the proband and her mother (heterozygous carrier). Levels of AP4E1, a subunit of the AP-4 complex, are reduced, indicating that no stable AP-4 is formed. ATG9A, a main cargo protein of AP-4, is robustly increased consistent with AP-4 deficiency. (B) Immunocytochemistry and high-content confocal imaging of fibroblasts derived from the proband and her mother (heterozygous carrier) demonstrate an accumulation of the AP-4 cargo protein ATG9A in the transGolgi network (marker: TGN46) suggesting a loss of AP-4 function. Line blots demonstrate the colocalization of ATG9A fluorescence with the trans-Golgi network marker TGN46. Scale bar: $10 \mu \mathrm{m}$. $p$ Values are denoted as follows: $p<$ $0.05(*)$ and $p<0.0001$ (****). AP4E1 = Adaptor Related Protein Complex 4 Subunit Epsilon 1; ATG9A = Autophagy Related Protein 9A; $A U$ = arbitrary units; TGN = trans-Golgi network. 
of SPG50 and other forms of AP-4-associated hereditary spastic paraplegia, found in over $90 \%$ and $60 \%$ of patients, respectively. ${ }^{3,4}$ In combination with the clinical features of infantile-onset hypotonia, early-onset moderate to severe developmental delay, episodes of stereotypic laughter, and seizures, the clinical presentation is well within the spectrum of SPG50. ${ }^{3,4}$ This was further corroborated by the presence of a variant in AP4M1 that disrupts a canonical splice site. Functional studies in patient-derived fibroblasts show loss of adaptor protein complex 4 function providing support for the pathogenicity of the variant.

It is notable that features seen in the majority of individuals with AP4M1-associated SPG50 such as spasticity and microcephaly ${ }^{3,4}$ are absent. This points to an ameliorated or blended phenotype, i.e., the relative macrocephaly seen in SRS may have mitigated the postnatal microcephaly that develops in the majority of children with SPG50. On the other hand, refractory epilepsy is only found in $\sim 25 \%$ of patients with AP-4-associated hereditary spastic paraplegia ${ }^{3,4}$ and is typically associated with a more severe disease course. ${ }^{4}$ It is interesting to speculate that other genes affected by $\operatorname{UPiD}(7)$ mat may act as modifiers. Blended phenotypes of SRS due to $\mathrm{UPiD}(7)$ mat and pathogenic variants of genes in the area of homozygosity have been reported to cause cystic fibrosis $(C F T R)^{9}$ and myoclonus-dystonia (SGCE) ${ }^{10}$ but, to our knowledge, no genetic forms of epilepsy.

In conclusion, we report a patient with a blended phenotype of SRS and AP4M1-associated SPG50 caused by UPiD(7) mat. This highlights the importance of genetic testing for recessive diseases in patients with imprinting disorders, particularly when presenting with features outside of welldescribed syndromes.

\section{Acknowledgment}

The authors thank the patient and her family for their help and willingness to participate in this study.

\section{Study Funding}

M. Ziegler received a scholarship from the DAAD (German National Exchange Service). M. Ziegler and K. Eberhardt received support from the German National Academic Foundation. D. Ebrahimi-Fakhari reports grant support from the CureAP4 Foundation, the CureSPG50 Foundation, the Spastic Paraplegia Foundation, the Thrasher Research Fund, the National Institute of Health/National Institute of Neurological Disorders and Stroke (2R25NS070682), and Astellas Pharmaceuticals Inc. The BCH Intellectual and Developmental Disabilities Research Center Clinical/Translational Core, and Cellular Imaging Core are supported by the NIH (BCH IDDRC, 1U54HD090255).

\section{Disclosure}

M. Ziegler, B.E. Russell, K. Eberhardt, G. Geisel, and A. D'Amore report no disclosures. M. Sahin reports grant support from Novartis, Roche, Pfizer, Biogen, Ipsen, LAM
Therapeutics, Astellas, Bridgebio, and Quadrant Biosciences; he has served on scientific advisory boards for Sage, Roche, Celgene, Aeovian, Regenxbio, and Takeda. H.I. Kornblum reports no disclosures. D. Ebrahimi-Fakhari received an honorarium for speaking at the Movement Disorder International Congress in 2019 and reports research funding through a joint research agreement with Astellas Pharmaceuticals Inc. Go to Neurology.org/NG for full disclosures.

\section{Publication History}

Received by Neurology: Genetics August 26, 2020. Accepted in final form October 22, 2020.

Appendix Authors

\begin{tabular}{lll}
\hline Name & Location & Contribution \\
\hline $\begin{array}{ll}\text { Marvin } \\
\text { Ziegler }\end{array}$ & Boston Children's Hospital, & $\begin{array}{l}\text { Acquisition and analysis of } \\
\text { data and drafting a } \\
\text { significant portion of the } \\
\text { manuscript or figures }\end{array}$ \\
\hline
\end{tabular}

\begin{tabular}{|c|c|c|}
\hline $\begin{array}{l}\text { Bianca E. } \\
\text { Russell, MD }\end{array}$ & $\begin{array}{l}\text { David Geffen School of } \\
\text { Medicine at UCLA, Mattel } \\
\text { Children's Hospital, UCLA }\end{array}$ & $\begin{array}{l}\text { Acquisition and analysis of } \\
\text { data and drafting a } \\
\text { significant portion of the } \\
\text { manuscript or figures }\end{array}$ \\
\hline $\begin{array}{l}\text { Kathrin } \\
\text { Eberhardt }\end{array}$ & $\begin{array}{l}\text { Boston Children's Hospital, } \\
\text { MA }\end{array}$ & $\begin{array}{l}\text { Acquisition and analysis of } \\
\text { data }\end{array}$ \\
\hline $\begin{array}{l}\text { Gregory } \\
\text { Geisel, BS }\end{array}$ & $\begin{array}{l}\text { Boston Children's Hospital, } \\
\text { MA }\end{array}$ & $\begin{array}{l}\text { Acquisition and analysis of } \\
\text { data }\end{array}$ \\
\hline $\begin{array}{l}\text { Angelica } \\
\text { D'Amore, } \\
\text { PhD }\end{array}$ & $\begin{array}{l}\text { Boston Children's Hospital, } \\
\text { MA }\end{array}$ & $\begin{array}{l}\text { Acquisition and analysis of } \\
\text { data }\end{array}$ \\
\hline $\begin{array}{l}\text { Mustafa } \\
\text { Sahin, MD, } \\
\text { PhD }\end{array}$ & $\begin{array}{l}\text { Boston Children's Hospital, } \\
\text { MA }\end{array}$ & $\begin{array}{l}\text { Acquisition and analysis of } \\
\text { data and drafting a } \\
\text { significant portion of the } \\
\text { manuscript or figures }\end{array}$ \\
\hline $\begin{array}{l}\text { Harley I. } \\
\text { Kornblum, } \\
\text { MD, PhD }\end{array}$ & $\begin{array}{l}\text { Semel Institute for } \\
\text { Neuroscience, UCLA }\end{array}$ & $\begin{array}{l}\text { Conception and design of } \\
\text { the study, acquisition and } \\
\text { analysis of data, and } \\
\text { drafting a significant } \\
\text { portion of the manuscript } \\
\text { or figures }\end{array}$ \\
\hline $\begin{array}{l}\text { Darius } \\
\text { Ebrahimi- } \\
\text { Fakhari, MD, } \\
\text { PhD }\end{array}$ & $\begin{array}{l}\text { Boston Children's Hospital, } \\
\text { MA }\end{array}$ & $\begin{array}{l}\text { Conception and design of } \\
\text { the study, acquisition and } \\
\text { analysis of data, and } \\
\text { drafting a significant } \\
\text { portion of the manuscript } \\
\text { or figures }\end{array}$ \\
\hline
\end{tabular}

\section{References}

1. Eggermann T. Russell-Silver syndrome. Am J Med Genet C Semin Med Genet 2010; 154C:355-364.

2. Kotzot D. Maternal uniparental disomy 7 and Silver-Russell syndrome: clinical update and comparison with other subgroups. Eur J Med Genet 2008;51:444-451.

3. Ebrahimi-Fakhari D, Behne R, Davies AK, Hirst J. AP-4-associated hereditary spastic paraplegia. In: Adam MP, Ardinger HH, Pagon RA, et al, editors. GeneReviews. Seattle: University of Washington, Seattle; 1993.

4. Ebrahimi-Fakhari D, Teinert J, Behne R, et al. Defining the clinical, molecular and imaging spectrum of adaptor protein complex 4-associated hereditary spastic paraplegia. Brain 2020;143:2929-2944.

5. Teinert J, Behne R, D'Amore A, et al. Generation and characterization of six human induced pluripotent stem cell lines (iPSC) from three families with AP4B1-associated hereditary spastic paraplegia (SPG47). Stem Cell Res 2019;40:101575.

6. Behne R, Teinert J, Wimmer M, et al. Adaptor protein complex 4 deficiency: a paradigm of childhood-onset hereditary spastic paraplegia caused by defective protein trafficking. Hum Mol Genet 2020;29:320-334. 
7. Azzi S, Salem J, Thibaud N, et al. A prospective study validating a clinical scoring system and demonstrating phenotypical-genotypical correlations in Silver-Russell syndrome. J Med Genet 2015;52:446-453.

8. Wakeling EL, Amero SA, Alders M, et al. Epigenotype-phenotype correlations in Silver-Russell syndrome. J Med Genet 2010;47:760-768.
9. Hehr U, Dorr S, Hagemann M, Hansmann I, Preiss U, Bromme S. Silver-Russell syndrome and cystic fibrosis associated with maternal uniparental disomy 7. Am J Med Genet 2000;91:237-239.

10. Augustine EF, Blackburn J, Pellegrino JE, Miller R, Mink JW. Myoclonus-dystoni syndrome associated with Russell Silver syndrome. Mov Disord 2013;28:841-842. 


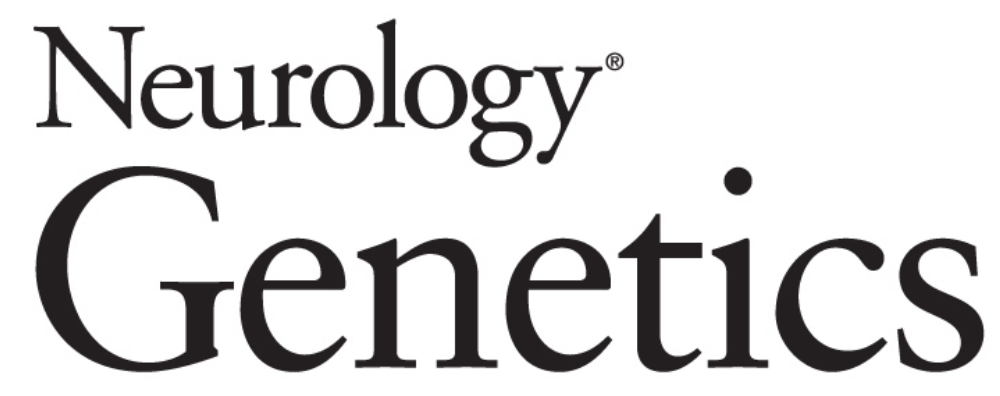

\section{Blended Phenotype of Silver-Russell Syndrome and SPG50 Caused by Maternal Isodisomy of Chromosome 7}

Marvin Ziegler, Bianca E. Russell, Kathrin Eberhardt, et al. Neurol Genet 2021;7;

DOI 10.1212/NXG.0000000000000544

\section{This information is current as of December 29, 2020}

\section{Updated Information \&} Services

References

Citations

Permissions \& Licensing

Reprints including high resolution figures, can be found at: http://ng.neurology.org/content/7/1/e544.full.html

This article cites 9 articles, 2 of which you can access for free at: http://ng.neurology.org/content/7/1/e544.full.html\#\#ref-list-1

This article has been cited by 1 HighWire-hosted articles: http://ng.neurology.org/content/7/1/e544.full.html\#\#otherarticles

Information about reproducing this article in parts (figures,tables) or in its entirety can be found online at:

http://ng.neurology.org/misc/about.xhtml\#permissions

Information about ordering reprints can be found online: http://ng.neurology.org/misc/addir.xhtml\#reprintsus

Neurol Genet is an official journal of the American Academy of Neurology. Published since April 2015, it is an open-access, online-only, continuous publication journal. Copyright Copyright $\odot 2020$ The Author(s). Published by Wolters Kluwer Health, Inc. on behalf of the American Academy of Neurology.. All rights reserved. Online ISSN: 2376-7839.

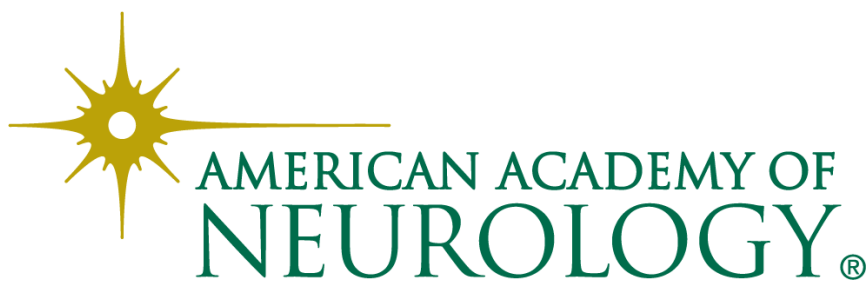

